\title{
STRATEGIC MARKETING DECISIONS OF INDUSTRIAL BUSINESS ORGANIZATIONS
}

Introduction. The dynamics of supply and demand in industrial markets, the competitive business environment, the technologies and innovations of industrial products, as well as the development of modern management approaches require that modern industrial business organizations seek management tools in order to achieve sustainability in implementing adopted marketing strategies. A way to achieve this is to apply accurate procedures and prescriptions for making strategic marketing decisions considered as a component of the strategic marketing management in industrial enterprises.

1. Characteristics of strategic marketing in modern industrial business organizations

Over the last decades, the importance of strategic marketing has increased when managing industrial companies. This is mainly due to the pursuit of accurately predicting the future of markets and the business environment, reducing the risk of possible threats, achieving sustainable conditions for development, as well as to the realized importance of marketing achievements in implementing business strategies adopted by organizations. The need for a strategic marketing objective that the entire marketing activity should be oriented to and the necessity to develop the strategic thinking of marketing managers are the basis of similar processes. All these factors create the need to develop and execute marketing strategies in industrial companies. Essentially, these strategies focus on the B2B marketplace, product development and technological innovations, price flexibility, sale, or appropriate communication tools. Their diversity creates prerequisites for alternatives, opportunities for timely and proper response to unexpected situations or to the emergence of new market trends, as well as for optimized management of operational marketing activities.

In industrial business organizations strategic marketing management (marketing management through marketing strategies) is recognized as an activity performed by managers, which relies on human potential as the basis of organizations, orients business activities to the needs of consumers, performs flexible regulation and timely changes in organizations that meet the challenges of the environment and allow for competitive advantage. All these enable organizations to survive and achieve their objective in the long run [adapted from: 1, p. 183].

In modern industrial enterprises, the classic formulations of a marketing strategy, seen as "a common plan for marketing activities by which a company expects to achieve its marketing goals" [2, p. 106], are being renewed. A marketing strategy traditionally refers to the process of planning and executing various marketing activities subject to the achievement of the set corporate goals. Modern trends in the concept of marketing strategy result from the changing role of marketing as [adapted from: 3, p.13]:

- an integral part of an organization's strategy determining its long-term benefits;

- a participant in organizational changes, requiring the creation of more flexible management structures;

- a prerequisite for the development of corporate culture enhancing the motivation of associates and their interest in the final business outcomes;

- a major factor in creating good long-term relationships with customers and partners;

- changing the way of thinking and the priorities of all contributors within an organization;

- an enhancer for significant management transitions: from marketing in a department to marketing within an organization, from tangible to intangible assets, from profit-earning transactions to long-term consumer profitability, from financial to marketing metrics.

The concept of industrial strategic marketing focuses on using B2B market information, identifying the 'right business consumer' and designing a competitive market position for a company. In this way, marketing strategies of industrial companies practically bind industrial markets and industrial products together, thus guaranteeing the existence of enterprises.

Strategic marketing management, as a management approach, along with the developed complex of marketing strategies, determine the future of an industrial enterprise in the long run, orienting it to achieving set strategic marketing objectives and agreed actions for managing demand. One of the main objectives of this complex is to create conditions under which a company not only avoids market problems, but also realizes achievements such as increasing its market share, entering new target markets, etc. As an integral part of the corporate strategy of industrial enterprises, marketing 
strategizing faces major tasks related to the direction of business expansion, increasing the technological potential for expanding production capacity, product innovation, conquering new markets, etc. In addition, the marketing strategy of industrial enterprises determines the way the marketing structure is organized.

2. Specifics of strategic marketing decisions in industrial business organizations

Achieving the objectives and tasks of strategic marketing management in an industrial enterprise is im- plemented through a strategic decision-making process. It includes decisions generally related to formulating a marketing strategy, its implementation, evaluation and the degree of its implementation, as well as to changing the strategy when irrelevance is identified.

The varieties of strategic decisions are also defined by marketing strategies as tools for solving strategic problems with long-term effects and key importance to industrial enterprises. From this point of view, a portfolio of key strategic marketing decisions is created as presented in Fig. 1.

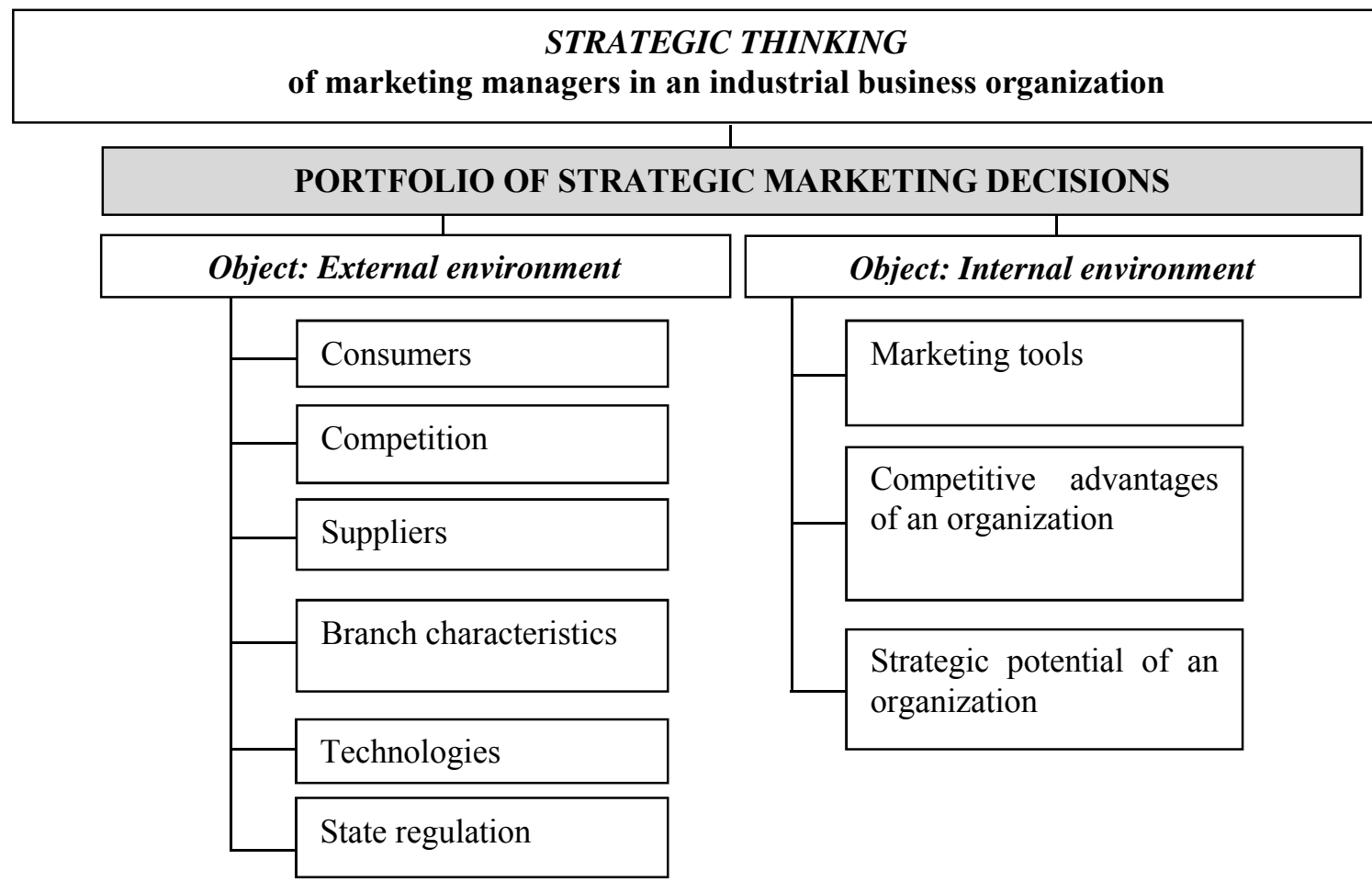

Fig. 1. A portfolio of key strategic marketing decisions in an industrial business organization

The position strategic marketing decisions hold in relation to the corporate strategy of industrial organizations ranks them in three levels presented in Fig. 2.

Strategic decisions related to the formation and implementation of a marketing strategy are an integral part of the management of industrial enterprises. The following groups of factors affect their development:

- trends in the external marketing environment related to market demand, requirements of consumer organizations, distribution conditions, legal regulation, and territorial distribution;

- state of competition in supply, major competitors and strategic fields of their activity;

- industrial enterprise potential and management resources (product, financial, commercial, personnel, scientific, technical, information) and defining its strategic advantages;

- basic concept for the development of an enterprise, strategic goals and objectives of the business in its main strategic fields.
Taking the above mentioned factors into account enables marketing managers to choose the most appropriate ways to work in different markets.

When implementing a marketing strategy, decisions made are allocated according to the stages of development of this process, namely:

1) Decisions on major components of market environment. In the long run, determinants of demand and competition which are in permanent dynamic dependence are crucial.

2) Decisions related to the availability of resources and the management potential of an industrial organization. The advantages and disadvantages of competitors are justified here.

3) Decisions on synchronizing enterprise potential with the interests of individual segments of consumer organizations. Thus, a target market with regard to which an enterprise develops its competitive advantages is identified. 
4) Decisions on creating a set of marketing activities. Impact is made on the target market by which an enterprise can realize its competitive advantages and achieve development in the perspective outlined by the marketing strategy.

Various management approaches are applied when making the presented strategic marketing decisions.

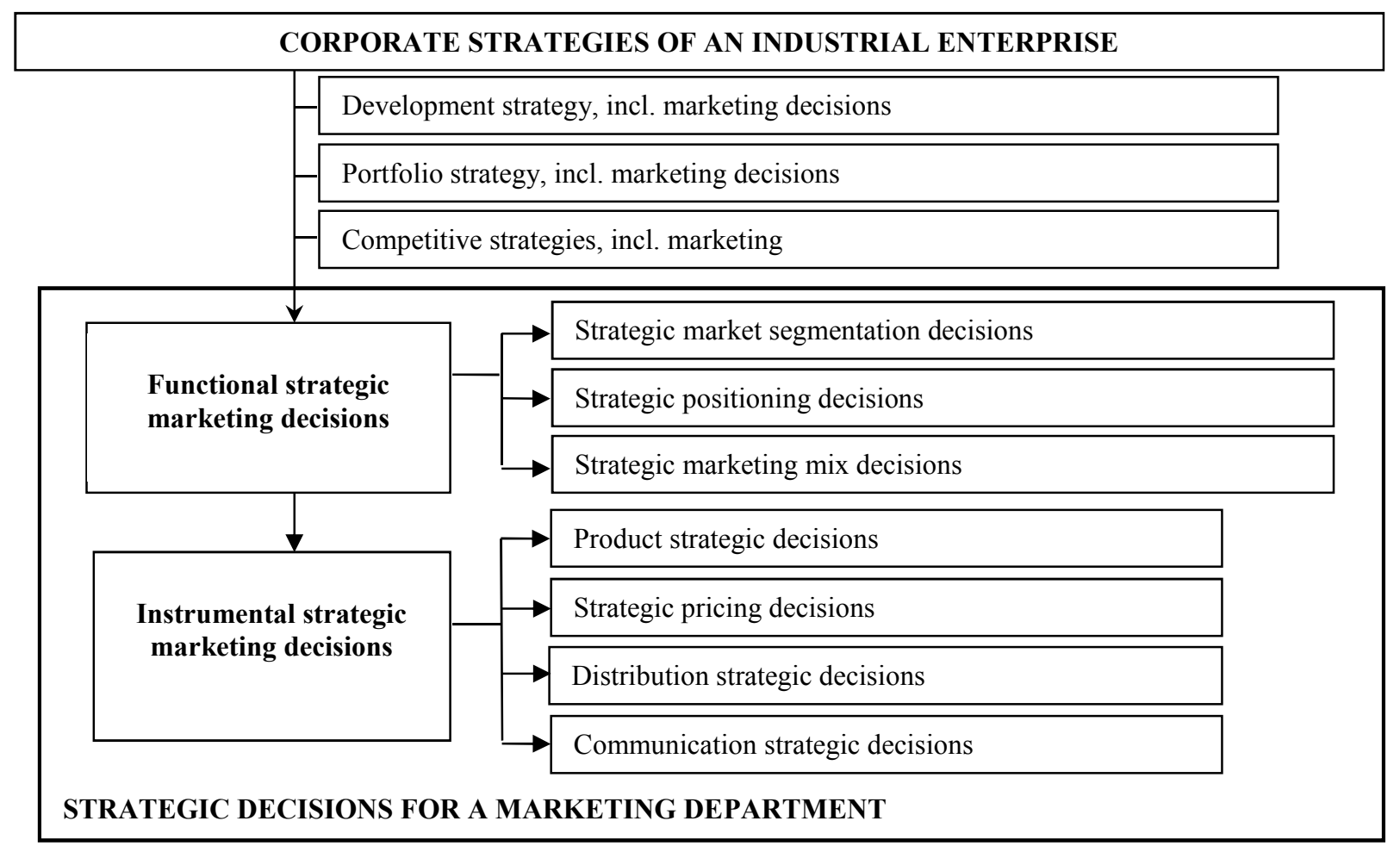

Fig. 2. A system of strategic marketing decisions of an industrial enterprise

3. Strategic marketing decision-making approaches in industrial business organizations

In industrial organizations, strategic marketing decisions can be made through management approaches, including the following:

- An approach to making 'unstructured' strategic decisions. Brothers, Andriessen, and Nicolaes [4, p. 132] determine three phases of this process through empirical research:

- Identification. Includes two options: a) managers recognize that something happens and it presents a problem or opportunity (changes in enterprise environment, etc.); b) managers have reliable information about the change and events are well understood.

- Development. It consists of two sub-processes: a) search for internal and external periodic decisions for recurring events; b) generating potential decisions or modifying existing ones to adapt to new conditions.

- Selection. It comprises three sub-processes: a) screening and detailed study of the alternatives generated in the previous phase; b) selecting and evaluating alternative decisions by analyzing and arbitrating them; c) making a final decision by reviewing the specifics of strategic alternatives.

Studying practices applied in different industries shows that this process is affected by factors such as pur- suit of rationality, forces and policies within organizations, and external control.

- A rational decision-making approach. With it, strategic decisions are perceived as a kind of rational decisions, defined by Rue and Byars [5, p. 52]. Rational decisions include assessing factual information through deduction and can be optimizing and satisficing. The optimization approach (sometimes completely identified with the rational one) involves the following steps:

1) Recognizing the need for a decision.

2) Identifying, ranking and weighing decisionmaking criteria.

3) Collecting the necessary accessible information and data.

4) Identifying possible alternatives.

5) Evaluating alternatives with regard to each criterion.

6) Choosing the best alternative.

When the need to make a strategic marketing decision of the 'satisficing' type is realized, the main criterion is the expected outcomes of implementing the decision which are ranked according to their interrelated importance. In addition, interests of in-company groups (labour unions, informal groups), decision-makers (managers and contractors) and their personal characteristics (individual personal environment and experience) are taken into account, as well as dimensions such as 
position, structure, objectives and traditions of an enterprise.

- A situational approach to strategic decisionmaking. Dikhtl' and Khërshen [6, p. 12] give a detailed description of the stages of decision-making depending on a particular situation. The main phases with their corresponding sub-phases are as follows:

1) Identifying the problem: Describing the problem $\rightarrow$ Structuring the problem;

2) Developing a concept of data collection: Creating a model $\rightarrow$ Determining the purpose of data collection $\rightarrow$ Formulating hypotheses $\rightarrow$ Designing a research project (sources of information, contractors) $\rightarrow$ Research plan (loss of time, value) $\rightarrow$ Determining the method of data collection;

3) Field studies: Selecting and developing data collection tools $\rightarrow$ Determining the object of study and the volume of the panel $\rightarrow$ Data processing $\rightarrow$ Developing a detailed plan for data collection $\rightarrow$ Organization, implementation and control of data collection $\rightarrow$ Documentation;

4) Data analysis: Preliminary verification of collected information $\rightarrow$ Preparing for a computer analysis $\rightarrow$ Material processing $\rightarrow$ Interpretation of results $\rightarrow$ Preparing a research report;

5) Presenting and delivering to decision-makers.

- 'Minimax', 'Maximin' and risk proofing approaches $^{1}$. In this aspect, several types of decision-making conditions can be distinguished, namely:

- security - in a security situation, managers can specify the results for each alternative;

- risk - managers can often, and at certain costs, obtain information on various possible outcomes in order to prevent a risk situation by using a value analysis of expected payments for each alternative, such as a mathematical calculation based on probability of occurrence;

- uncertainty - the 'minimax' (optimistic), 'maximin' (pessimistic), and the risk-averting (supports effective planning) approaches are applied when managers have little or no information to evaluate various possible outcomes.

- Strategic decision-making approach in strategic uncertainty. Based on the strategic management theory, Belorus, Rogach and Chekerda [8] define the tools used to make decisions in the event of strategic uncertainty. One of them is the management system through ranking strategic tasks by: *constantly monitoring changes in the environment; *reporting the results from analyzing changes and assessing the degree of urgency to make a decision (a problem or a new opportunity found); *classifying and categorizing tasks with constantly revising,

${ }^{1}$ These approaches are related to the management concept of decision theory studying the choice of economic agents [7]. It develops in two directions: *normative decision theory - analyzes results from decisions or determines the optimal decisions, given limitations and hypotheses; *descrip- updating and ranking their structure in order to make the right decision. This system is perfectly appropriate for strategic marketing decisions, with decision-making and implementing being controlled by taking into account important strategic effects not only for marketing but also for the entire enterprise.

When applying the above mentioned approaches, each industrial enterprise must choose the most appropriate one on the basis of a serious analysis as well as the correct market behaviour, supported by a procedure, which will ensure the achievement of the adopted strategic marketing objective.

\section{Conditions and recommendations for strate-} gic decision-making

The necessary conditions for making the right decision in an industrial enterprise include the presence of:

- a database of up-to-date data describing the status of the issue;

- various alternatives among which to choose one or more;

- criteria for comparing alternatives according to the degree to which the objectives of an enterprise are achieved;

- objectives and individual qualities of particular employees or managers making decisions;

- decision-making tools, additional data collection, analysis, forecasts of the consequences of decisionmaking, etc.

In the process of making strategic marketing decisions in an industrial enterprise, it is possible to affect the objective sources or subjective preferences of decision-makers, as well as the process itself, through the following:

- creating conditions for selling products whose consideration as initial information in decision-making brings benefits to a particular enterprise;

- adopting criteria for comparing alternatives that help the objectives of decision-makers to correspond to those of an enterprise;

- unrealistic assessment of basic information and decision-making with emphasis on individual inclinations and the quality of decision-makers.

This means that in making this type of decisions, industrial organizations must follow some basic recommendations, such as:

- Strategic marketing of an enterprise requires a purposeful, well-coordinated management approach in a framework integrating marketing tools.

- It is necessary to establish a specialized strategic unit in an enterprise, which will serve the formulation and implementation of the marketing strategy, solve

tive decision theory - analyzes how business agents make decisions that they need to execute. It is also closely related to the 'game theory' and 'probability theory'. The practical application of decision theory is implemented by statistical and econometric methods. 
strategic problems and apply the adopted procedure for strategic decision-making. If such a unit cannot be set up, it is necessary to train individual managers or to involve external specialists in strategic marketing management.

- If strategic risks and crises in industrial marketing are to be overcome, the following activities should be implemented:

- develop a predictive system, i.e. a sensible perception of the moment a crisis is expected to occur;

- develop a system of measures in case of strategic uncertainty related to information overload, inadequacy of marketing activities, existing irrelevance of marketing strategy, etc;
- determine all possible causes for a possible crisis and the so-called 'crisis centres' in an enterprise;

- assess the degree of danger of each possible crisis;

- eliminate the impact of the 'crisis centres'.

In case problems arise when implementing the strategic decision-making procedure, certain possible actions for eliminating them are suggested in Table.

The recommendations presented here do not completely exhaust the possibilities for ensuring the proper implementation of the strategic decision-making process, as well as for overcoming potential risks and threats with the marketing strategizing in industrial business organizations.

Solutions to some problems in the course of making strategic marketing decisions

Table

\begin{tabular}{|l|l|}
\hline \multicolumn{1}{|c|}{ Problems } & \multicolumn{1}{c|}{ Management decisions } \\
\hline Using only quality marketing analytics tools & $\begin{array}{l}\text { Increased use of modern software quality approaches and mar- } \\
\text { keting analytics tools }\end{array}$ \\
\hline $\begin{array}{l}\text { Insufficient/missing information or fragmented/ } \\
\text { missing strategic decision-making analysis }\end{array}$ & $\begin{array}{l}\text { Obtaining analytical information and firmly renouncing intui- } \\
\text { tive strategic decision-making }\end{array}$ \\
\hline $\begin{array}{l}\text { Impact of unsubstantiated opinions on managerial } \\
\text { staff }\end{array}$ & $\begin{array}{l}\text { Improving the scanning of the external and internal marketing } \\
\text { environment }\end{array}$ \\
\hline
\end{tabular}

Conclusion. Identifying the specifics of strategic decisions in marketing, as well as the contemporary approaches for making this type of decisions in industrial business organizations emphasizes their significance for modern marketing management. This gives grounds for such decisions to be defined as a strategic management tool suitable for several purposes: determining the right strategic direction for these enterprises, successfully implementing the marketing strategy and revising it when needed, and overcoming strategic marketing issues with long-term effects on their business. Strategic marketing decisions are further evidence of the benefits of purposeful long-term management and have successfully revealed their potential in modern industrial organizations.

\section{Literature}

1. Виханский О., Наумов А. (2010). Менеджмент. Москва: ИНФРА-М. 2. Ансофф, И. (2001). Стратегическое управление. Москва. 3. Шишло О., Андросик Ю. (2017). Стратегический маркетинг. Минск: БГТУ. 4. Brothers, K., Andriessen, F., Nicolaes, I. (1998). Driving Blind: Strategic Decision-making in Small Companies. Long Range Planning, 31(1), 130-138. Downloaded on 12.03.2016. URL: files.aiscience.org/ journal/article/pdf/70330023.pdf. 5. Rue, L., Byars, L. (1992). Management: Skills and Application (issue 6). Burr Ridge-Boston-Sydney: IRWIN. 6. Дихтль, Е., Хёршен, Х. (1996). Практический маркетинг. Москва. 7. Steele, K., Stefánsson, H. (2015). Decision Theory. From: The Stanford Encyclopedia of Philosophy. 8. Белорус, О., Рогач, В., Чекерда, А. (1992). Менеджмент предприятия в условиях неожиданностей. Экономика Украиныл. № 2. С. 42-46.

\section{References}

1. Vikhansky O., Naumov A. (2010). Management. Moscow, INFRA-M [in Russian].

2. Ansoff I. (2001). Strategic management. Moscow [in Russian].

3. Shishlo O., Androsik Yu. (2017). Strategic marketing. Minsk, BSTU [in Russian].

4. Brothers K., Andriessen, F., Nicolaes, I. (1998). Driving Blind: Strategic Decision-making in Small Companies. Long Range Planning, 31(1), 130-138. Downloaded on 12.03.2016. Retrieved from files. aiscience.org/journal/article/pdf/70330023.pdf.

5. Rue L., Byars L. (1992). Management: Skills and Application (issue 6). Burr Ridge-Boston-Sydney: IRWIN.

6. Dichtl E., Horshen, H. (1996). Practical marketing. Moscow [in Russian].

7. Steele K., Stefánsson H. (2015). Decision Theory. From: The Stanford Encyclopedia of Philosophy.

8. Belarus O., Rogach V., Chekerda A. (1992). Management of the enterprise in the face of surprises. Economy of Ukraine, 2, pp. 42-46 [in Russian].

Григорова В. Стратегічні маркетингові piшення промислових бізнес-організацій

Проблемою дослідження цієї статті є стратегічні рішення, прийняті при формулюванні та реалізації маркетингових стратегій організацій промислового бізнесу. Основна мета полягає в тому, щоб розкрити потенціал стратегічних маркетингових рішень як сучасного інструменту управління маркетинговою стратегією, позначивши позицію, яку цей тип рішень займає в стратегічному маркетингу в промисловому секторі, характеризуючи їх специфіку і типологію, пока- 
зуючи можливі підходи і процедури для прийняття таких рішень, винесення рекомендацій щодо їх успішного впровадження як процесу і подолання можливих проблем.

Ключові слова: стратегічне управління маркетингом, стратегічні маркетингові рішення, підходи до прийняття стратегічних рішень, організація промислового бізнесу.

Grigorova V. Strategic Marketing Decisions of Industrial Business Organizations

The research problem of the present concept study is the strategic decisions made when formulating and implementing the marketing strategies of industrial business organizations. The main objective is to reveal the potential of strategic marketing decisions as a modern management tool in marketing strategizing by outlining the position this type of decisions holds in strategic marketing in the industrial sector, characterizing their specifics and typology, showing possible approaches and procedures for making such decisions, making recommendations for their successful implementation as a process and overcoming possible problems.
Keywords: strategic marketing management, strategic marketing decisions, strategic decision-making approaches, industrial business organization.

Григорова В. Стратегические маркетинговые решения промышленных бизнес-организаций

Проблемой исследования настоящей статьи являются стратегические решения, принимаемые при формулировании и реализации маркетинговых стратегий организаций промышленного бизнеса. Основная цель состоит в том, чтобы раскрыть потенциал стратегических маркетинговых решений как современного инструмента управления маркетинговой стратегией, обозначив позицию, которую этот тип решений занимает в стратегическом маркетинге в промышленном секторе, характеризуя их специфику и типологию, показывая возможные подходы и процедуры для принятия таких решений, вынесения рекомендаций по их успешному внедрению в качестве процесса и преодолению возможных проблем.

Ключевые слова: стратегическое управление маркетингом, стратегические маркетинговые решения, подходы к принятию стратегических решений, организация промышленного бизнеса.

Received by the editors: 10.12.2019 and final form 19.12.2019 